PRACE GEOGRAFICZNE

zeszyt 160, 2020, 29-51

doi: 10.4467/20833113PG.20.004.12262

Instytut Geografii i Gospodarki Przestrzennej UJ

Komisja Geograficzna, Polska Akademia Umiejętności

Wydawnictwo Uniwersytetu Jagiellońskiego

\title{
„Bo to jest idealna praca dla mnie!” - \\ MOTYWY AKTYWIZACJI ZAWODOWEJ KOBIET \\ POPRZEZ AGROTURYSTYKE
}

Magdalena Kubal-Cæerwińska

„Because that's a perfect job for me!” -

Motives of women's professional activation through agritourism

Abstract: The subject of this study is the process of women's professional activation, which takes place as a result of undertaking agritourism activities on farms in rural areas of the Polish Carpathians. The main purpose of the article was to determine the motives of women to undertake professional activity in rural tourism. The study included a sample of 70 agritourism farms run or co-run by women in Carpathian rural tourist communes in the Lesser Poland (Małopolska) Voivodeship. Three groups of motives, which guided women while choosing their path of professional activation in agritourism, were distinguished. The basis for undertaking agritourism activities are expected economic benefits and factors arising from the spatial environment of farms such as local hospitality traditions, the level of tourism development, the presence of attractive values for leisure, the traditional village life, and the "internal" factors associated with household and agricultural resources. Equally important are the "individualistic" motifs of psychological and social nature - the need to contact other people or be "needed" in the family. The female professional activation in agritourism has not only an economic but also a social and cultural dimension.

Keywords: professional activation, women, agritourism, rural areas, Lesser Poland Voivodeship (the Małopolska Voivodeship), Carpathians 
Zarys treści: Przedmiotem pracy jest proces aktywizacji zawodowej kobiet, który dokonuje się w rezultacie podejmowania działalności agroturystycznej w gospodarstwach rolnych na obszarach wiejskich polskich Karpat. Celem głównym artykułu uczyniono określenie motywów podjęcia przez kobiety na obszarach wiejskich działalności zawodowej w agroturystyce. Badaniem objęto próbę 70 gospodarstw agroturystycznych, prowadzonych lub współprowadzonych przez kobiety, w karpackich gminach turystycznych wiejskich w województwie małopolskim. Wyróżniono 3 grupy motywów, którymi kierowały się kobiety przy obieraniu swojej ścieżki realizacji zawodowej w działalności agroturystycznej. U podstaw motywów podjęcia działalności agroturystycznej leżą spodziewane korzyści ekonomiczne oraz czynniki płynące z przestrzennego otoczenia gospodarstw rolnych, jak: lokalne tradycje gościnności, poziom rozwoju zjawisk turystycznych, obecność atrakcyjnych walorów dla wypoczynku, tradycyjne życie wsi, a także czynniki „wewnętrzne”, związane z zasobami gospodarstwa domowego i rolnego. Równie ważne są motywy „indywidualistyczne” o podłożu psychologicznym i społecznym - potrzeba kontaktu z innymi ludźmi i bycia „potrzebną” w rodzinie. Wyniki badania wskazują, że aktywizacja zawodowa kobiet w agroturystyce ma nie tylko wymiar ekonomiczny, ale także społeczny i kulturowy.

Stowa kluczowe: aktywizacja zawodowa, kobiety, agroturystyka, obszary wiejskie, województwo małopolskie, Karpaty

\section{Wprowadzenie}

Jednym z podstawowych problemów społecznych podejmowanych w badaniach geografii społeczno-ekonomicznej jest aktywność ludzka, motywacje do tej aktywności oraz jej rola w przeobrażeniach rzeczywistości społecznej (Seręga 1993). Motywy podejmowania aktywności ekonomicznej i zawodowej człowieka w przestrzeni stały się przedmiotem badań podejścia realistycznego w badaniach nad obszarami wiejskimi. W podejściu tym wiejski obszar (peryferyjny) to system lokalny o specyficznych cechach, w którym zachodzą zmiany funkcji i struktury funkcjonalnej pod wpływem działalności ekonomicznej i powiązanej z nią organizacji przestrzeni oraz organizacji dziennego cyklu życia (Wójcik 2011). W tym systemie kładzie się nacisk na kwestie współzależności pomiędzy typami produkcji (rynków pracy) a zjawiskami społecznymi, które znajdują odzwierciedlenie w pojęciu kapitału społecznego, rozwoju lokalnego, aktywizacji społeczności lokalnej oraz dyfuzji kulturowej. Jednostki są w stanie mobilizować swe siły i wpływać skutecznie na sposób rozwoju lokalnego poprzez własną ukierunkowaną aktywność. Mobilizacja indywidualna daje więc większe szanse powodzenia przedsięwzięcia aniżeli odgórne decyzje i działania organów scentralizowanych na szczeblu krajowym, regionalnym i lokalnym. Indywidualna samozaradność może stanowić czynnik katalizujący przemiany aktywności społecznej (Seręga 1993).

Przedmiotem niniejszej pracy jest rozpoznanie motywów prowadzących do procesu aktywizacji zawodowej kobiet, który dokonuje się w rezultacie podejmowania 
działalności agroturystycznej w gospodarstwach rolnych na obszarach górskich polskich Karpat. Aktywizacja zawodowa jest rozumiana, za Seręgą (1993), jako szczególny, złożony i wieloaspektowy fenomen społeczny obejmujący: ogót sjawisk

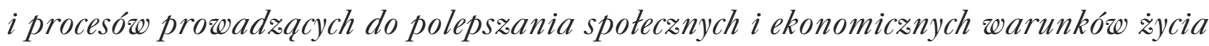
ludności poprzez saprowadzenie odpowiednich smian, które wymagajq indywidualnej,

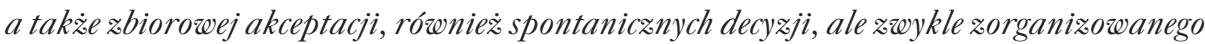
wysitku w skali rodziny i społecæności lokalnej. W tej pracy, szczególnym przedmiotem zainteresowania są motywy podjęcia aktywności zawodowej o charakterze indywidualnym, które stały się istotnym czynnikiem, decydującym o podjęciu pracy w agroturystyce przez kobiety z obszarów wiejskich.

Problematyka aktywizacji zawodowej kobiet w Polsce, motywacji do tej aktywności zawodowej mieści się w kręgu zainteresowań władz na szczeblu krajowym i lokalnym, wśród których kwestia ta rozpatrywana jest z perspektywy sytuacji rynku pracy (np. Ustawa \& dnia 20 kwietnia 2004 r. o promocji «atrudnienia i instytucjach rynku pracy, Dz.U. 2004 nr 99 poz. 1001). W tym kontekście działania władz ukierunkowane są na przygotowanie i pobudzanie osób do samodzielnego poszukiwania i podjęcia zatrudnienia. Dlatego pomocna wydaje się interpretacja pojęcia aktywizacji zawodowej jako: pobudzania jednostki do określonych sachowań, aktywności, stymulacji, uruchomienia procesu, który doprowad:a do podejmowania dziatań wyptywajacych z wewnętrwnej motywacji (Stownik Języka Polskiego PWN 2015).

Turystyka stwarza możliwości podjęcia pracy kobietom o różnym poziomie kwalifikacji zawodowych. Często są to prace niskopłatne, niedające szans na rozwój osobisty i awans zawodowy (Koutsou i in. 2010; Scheyvens 2000). Mimo tak niekorzystnej dla kobiet sytuacji na rynku pracy w turystyce dotychczasowe badania wskazują jednak, że uzyskują one korzyści z tej aktywności (Tew, Barbieri 2012). Na obszarach, gdzie turystyka zaczyna mieć istotne znaczenie w gospodarce lokalnej, kobiety stają przed decyzją, czy pracować - formalnie lub nieformalnie w branży turystycznej, aby zapewnić dodatkowy dochód w gospodarstwie domowym - czy poprzestać na wypełnianiu obowiązków domowych (Tew, Barbieri 2012). W tej sytuacji kobiety decydują się na dokonanie racjonalnego rachunku zysków i strat, korzyści i kosztów, które będą wynikiem podjęcia lub nie tejże aktywności zawodowej. Dotyczy to zarówno przestrzeni zawodowej, jak i obowiązków związanych ze sferami: rodzinną i domową. Kluczową rolę odgrywają tu motywacje kobiet do podjęcia pracy zawodowej, jak i te wynikające z pełnienia ról matki i żony w sferze gospodarstwa rodzinnego i domowego. W wielu przypadkach kobiety przyjmują równocześnie ciężar pracy zawodowej i obowiązków domowych, decydując się na godzenie obu sfer obowiązków. 


\section{Kontekst teoretyczny badań}

Problematyka przeobrażeń obszarów wiejskich w dobie przemian gospodarczych i społecznych niesie ze sobą informacje oraz podstawy do zastanowienia się nad problemem aktywności ludzkiej i aktywizacji zawodowej różnych grup społecznych. Znaczenie problemu aktywności ludzkiej w dobie przemian, jak podkreśla Seręga (1993), wynika więc z faktu, że to właśnie działalność jednostki, przejawy tej działalności i zdolność do pokonywania barier oraz wykorzystywania szans decydują o kształcie nowego porządku społecznego. Rozważania w tym zakresie związane są z istniejącymi koncepcjami społecznymi, które koncentrują się m.in. wokół motywacji jednostki do działania w zakresie zapewnienia bytu ekonomicznego i określonego statusu społecznego. W tym kontekście istotne będą koncepcje wywodzące się z nauk społecznych i ekonomicznych: dywersyfikacji działalności gospodarczej na tle wielofunkcyjnego rozwoju gospodarstw rolnych, kapitału społecznego, rozwoju lokalnego i push/pull factors do badania motywów przedsiębiorczości indywidualnych właścicieli gospodarstw rolnych.

Dywersyfikacja działalności gospodarczej w obrębie istniejących gospodarstw rolnych uważana jest za jedną z nowych ścieżek ich rozwoju i dotyczy pomocy rolnikom w znalezieniu nowych lub komplementarnych do produkcji rolnej sposobów wykorzystania posiadanych zasobów (takich jak budynki gospodarskie, sprzęt rolniczy, pastwiska i lasy), które wcześniej były wykorzystywane w rolnictwie konwencjonalnym (Alsos i in. 2003; Hansson i in. 2013; Łobocki 2006), dla prowadzenia wielokierunkowej działalności. Działalność turystyczna gospodarstwa, w tym działalność agroturystyczna, czerpie z potencjału zasobów miejscowych gospodarstw (Kurek 1995). W kontekście koncepcji dywersyfikacji działalności gospodarstw rolnych szeroko podejmowane są badania nad zrozumieniem motywów leżących u podstaw decyzji dywersyfikacji działalności: ryzyko utrzymania obecnego profilu gospodarstwa i niepewność o byt, chęć rozwoju w kierunku świadczenia usług rynkowych, poprawa warunków finansowych, spełnienie osobistych aspiracji i dążeń, zwiększenie przychodów i poprawa warunków życia dla rodziny (Alsos i in. 2003; Barbieri, Mahoney 2009; McGehee, Kim 2004; McGehee i in. 2007; Meert i in. 2005). Badania nad sytuacją dochodową gospodarstw rolnych prowadzących działalność pozarolniczą dowodzą, iż możliwość osiągnięcia zysku stanowi główny motyw dywersyfikacji działalności gospodarstwa rolnego (Kołodziejczak 2004).

Koncepcja kapitału społecznego zweryfikowała nadrzędność kapitału ekonomicznego nad społecznym i kulturowym społeczności wiejskiej w kontekście harmonijnego i efektywnego rozwoju tych obszarów (Halamska 2009). Kapitał społeczny rozumiany jest tutaj jako właściwość, zasób i cecha społeczności, sprzyjająca efektywnym działaniom indywidualnych i zbiorowych aktorów społecznych (Działek 2011; Frykowski, Starosta 2006; Halamska 2009) i w tym ujęciu stanowi atrybut 
lokalnych grup społecznych, których członków łączą silne więzi, nawiązane dla celów indywidualnych, często wypływające z relacji przyjacielskich. Kapitał społeczny na wsi ma więcej cech lokalnych niż ten miejski: ludność obszarów wiejskich w pierwszej kolejności ufa rodzinie i „swoim” - dlatego zawiązywane są więzi społeczne, lokalna solidarność i współdziałanie, formalne i nieformalne struktury współpracy wykorzystujące istniejące zasoby (Bartkowski 2008; Fedyszak-Radziejowska 2006; Frykowski, Starosta 2006; Halamska 2009; Seręga 1993). Rozwój w kierunku wielofunkcyjnego rozwoju wsi, oparty o kapitał społeczny, zwiększa możliwości zatrudnienia dla mieszkańców w sektorze pozarolniczym i przyczynia się m.in. do rozwoju lokalnych sieci powiązań, wzrostu liczby nowych kontaktów między „starymi” a „nowymi” prowadzącymi pozarolniczą działalność gospodarczą, a także między nimi a wcześniej już istniejącymi instytucjami lub organizacjami (Bartkowski 2008).

Przemiany obszarów wiejskich, jak wskazuje Seręga (1993), dotyczą czterech płaszczyzn układów lokalnych: gospodarczej, politycznej, społecznej i kulturowej. W tej czterodzielnej rzeczywistości, istotne jest odnalezienie takich sfer aktywności ludzkiej, w których partycypacja społeczności lokalnej będzie czynnikiem pozytywnym, rozwojowym, będzie sprzyjać mobilizacji społecznej na rzecz rozwoju lokalnego. Założeniem koncepcji rozwoju lokalnego jest rozwój obszarów wiejskich m.in. w sferze życia społecznego, który ma służyć poprawie sytuacji wsi i obszarów wiejskich (Seręga 1993; Szymańska 2009). Koncepcja ta wykorzystuje lokalne zasoby ludzkie, wraz z ich wiedzą i wykształceniem, kreatywnością, oraz zasoby naturalne do tworzenia lokalnej bazy ekonomicznej, która przyczyni się do uzyskania lokalnej stabilizacji i poprawy sytuacji społeczno-gospodarczej właśnie na poziomie lokalnym (Gorlach 2007; Szymańska 2009). Inicjatywy oddolne: rozwój alternatywnej produkcji i usług, transfer oraz dyfuzja wiedzy i technologii, podwyższanie kwalifikacji zawodowych miejscowej ludności, ekonomiczne, materialne, organizacyjne i techniczne wspieranie działań na rzecz wykorzystania endogenicznych zasobów są gwarantem ciągłego rozwoju obszarów wiejskich (Gorlach 2007; Szymańska 2009). Seręga (1993) postuluje, iż w świetle koncepcji rozwoju lokalnego w przypadku przeobrażeń polskiego rolnictwa i wsi oraz wielofunkcyjnego rozwoju wiejskich obszarów górskich w Polsce konieczny jest zwrot ku lokalności oraz poszukiwanie nowych rozwiązań i mechanizmów rozwojowych. Ta lokalność jest tutaj rozumiana jako poczucie tożsamości i identyfikacji lokalnej, kształtowane przez stosunek do terytorium, zależność ludzkich zachowań i działań względem przestrzeni i sposobów jej wykorzystania. Seręga (1993) zakłada, że warunkiem twórczego działania jest bogactwo i ró:́norodność, odrębność i niepowtarzalność „ojczyæn prywatnych”, identyfikowane i motywujące jednostki właśnie na poziomie lokalnym. Zwrot ku lokalności zakłada poszukiwanie w środowiskach wiejskich, w chłopskiej tradycji i kulturze szans na odtworzenie i uruchomienie nowych zasobów potencjału wsi oraz realizacji przedsięwzięć gospodarczych, sprzyjających ochronie środowiska przyrodniczego (Seręga 1993). 
Do badania motywów podejmowania działalności przedsiębiorczych przez indywidualnych właścicieli gospodarstw rolnych i aktywizacji zawodowej w kontekście dywersyfikacji działalności gospodarstwa rolnego oraz wielofunkcyjnego rozwoju obszarów wiejskich wykorzystuje się również społeczną koncepcję push/pull factors. Przedsiębiorczość rozumie się w tym przypadku, za Shane'm i Venkataramanem (2000) i Shane'm (2003), jako twórczy proces, w którym przedsiębiorca odkrywa nowe możliwości, ocenia je oraz wykorzystuje zasoby (istniejące lub nowe), prowadzące do uruchomienia nowych przedsięwzięć w ramach prowadzonego gospodarstwa rolnego. Dywersyfikacja działalności gospodarstw poza rolnictwem może mieć miejsce dzięki motywacjom w postaci możliwości (uruchomienie nowego przedsięwzięcia lub relokacja posiadanych zasobów i/lub wykorzystanie szans), lub stanowić konieczność samą w sobie (Barrett i in. 2001; Bowler 1999). Przedsiębiorcy mogą być „wypychani” do prowadzenia działalności gospodarczej na podstawie niezadowolenia z obecnej sytuacji życiowej lub „przyciągani” do pracy poprzez możliwości pracy oraz satysfakcję osobistą (Schjoedt, Shaver 2007). Koncepcja ta szereguje motywy podejmowania działalności zawodowej w agroturystyce jako czynniki „wypychające” (push factors) i ,przyciągające” (pull factors).

\section{Czynniki i motywy rozwoju wielokierunkowego działalności gospodarstw rolnych}

Badania nad sytuacją dochodową gospodarstw rolnych prowadzących działalność pozarolniczą wskazują na możliwość osiągnięcia zysku i dodatkowych dochodów z działalności na zaspokajanie potrzeb rodziny jako główny motyw podejmowania aktywności pozarolniczej przez gospodarstwa rolne (Kołodziejczak 2004). Wśród pozostałych motywów podejmowania działalności pozarolniczej przez rolników wymienia się (Bukraba-Rylska 2008; Janiak 1996; Kłodziński 1999; Kołodziejczyk 2004a, 2004b; Kryński 2003; Kryński i in. 2002; Michalska 2012):

- poczucie bezpieczeństwa w zaspokajaniu podstawowych potrzeb dla rodziny i osiągnięcie pewnego poziomu standardu życia;

- potrzebę uznania, prestiżu, szacunku i docenienia osiągnięć;

- wykorzystanie swych umiejętności i predyspozycji, a także własnych cech osobowościowych;

- chęć decydowania o własnej pracy, obowiązkach, niezależność, realizację własnych zainteresowań;

- potrzebę samorealizacji i aktywizacji pozostających bez pracy członków rodziny;

- możliwości infrastrukturalne i wykorzystanie niezagospodarowanych przestrzeni w gospodarstwie domowym: wolne pokoje, położenie gospodarstwa w atrakcyjnym turystycznie terenie, 
- chęć kontaktu z innymi ludźmi;

- tradycje rodzinne w przyjmowaniu gości;

- motywacje stworzenia dla siebie miejsca pracy przy braku lub utracie stałego zatrudnienia;

- chęć powielania sukcesów odniesionych przez znajomych, podążenie za radą: sąsiada, doradcy zawodowego w gminie, członka rodziny; działalność koła gospodyń wiejskich i lokalnych stowarzyszeń.

Obecne gospodarstwa rolne na obszarach wiejskich, poza wymiarem ekonomicznym, funkcjonują głównie w wymiarze społecznym (Michalska 2012; Runowski, Siekierski 1995). Wysoka aktywność zawodowa mieszkańców tych gospodarstw jest pochodną tego, iż są to gospodarstwa, które charakteryzuje rodzinny stosunek pracy (Jarosz 1996). W takich gospodarstwach motywacje do aktywności zawodowej wynikają z wysokiej świadomości potrzeby pracy i stają się produktem rozwoju społecznego. Bodźcem do pracy dla jednostki staje się - poza chęcią przetrwania - tradycja, nawyki, preferowane wartości w danym środowisku, własna potrzeba osiągnięć lub też dominacji (Runowski, Siekierski 1995), a więc postawy i zachowania charakteryzujące postawy przedsiębiorcze, które realizują motywy podejmowania działalności, w tym o charakterze pozarolniczym. Dywersyfikację działalności gospodarstw rolnych w kontekście przedsiębiorczości wyznacza różnorodność form dochodowego wykorzystania czynników wytwórczych: pracy, kapitału i ziemi oraz wykorzystania ich przez społeczności lokalne w działalności rolniczej, produkcyjnej i okołorolniczej (Hunek 1993), a także angażowania ich w innowacyjne działania przedsiębiorcze, z założeniem osobistego ryzyka finansowego, psychicznego i społecznego, jak również rekompensaty pieniężnej i osobistej satysfakcji (Hisrich, Pater 1992; Kłodziński 1996; Sawicki 2007). Stąd też podstawowymi jednostkami gospodarczymi obszarów wiejskich są prywatne drobne firmy, jednoosobowe i rodzinne, elastyczne w modelu zarządczym i produkcji (Kłodziński 1996; Kłodziński, Rosner 1995). Ich właściciele tworzą miejsca pracy dla siebie i członków rodziny. Firmy te są szczególnie nastawione na: świadczenie usług produkcyjnych dla gospodarstw, przetwarzanie produktów rolnych, nierolnicze wykorzystanie potencjału gospodarstw rolnych, szeroko pojęte usługi w sektorze pozarolniczym, np. turystyka. Podmioty prowadzące pozarolniczą działalność gospodarczą stanowią „koło zamachowe” współczesnego rozwoju obszarów wiejskich.

Proces aktywizacji zawodowej kobiet można analizować również w kontekście (skuteczności) przywództwa (Pawlusiński 2005). W tym modelu ważna jest rola lidera lokalnego rozwoju, który w sposób formalny lub nieformalny wpływa na grupy społeczne lub jednostki. Do zakresu działań lokalnych liderów należy: motywowanie, inspirowanie, nakłanianie do określonych zachowań oraz pomaganie w realizacji założeń i celów. 


\section{Motywy podejmowania aktywności zawodowej przez kobiety na obszarach wiejskich}

Agroturystyka należy do tych rodzajów form pozarolniczej działalności gospodarstwa rolnego, która wysoce uzależniona jest od warunków otoczenia (czynniki zewnętrzne, obiektywne), ale również od motywacji wewnętrznych i kompetencji właścicieli gospodarstwa (czynniki wewnętrzne, subiektywne) (Jachimowicz, Krzyżanowska 1998). Kobiety podejmują się realizacji agroturystycznej działalności gospodarstwa częściej niż mężczyźni (Peeters, Ateljevic 2009; Phelan, Sharpley 2011, 2012). Pojawianie się działalności agroturystycznej w gospodarstwie rozwija się na podstawie podobnych zasad, jak pojawianie się innowacji w gospodarstwach rolnych (Kurek 1995).

Rozpoczęcie działalności agroturystycznej jako pozarolniczej działalności gospodarstwa rolnego wiąże się z chęcią pozyskania nowych źródeł dochodu, gdy tradycyjna działalność rolnicza nie zaspokaja potrzeb alimentacyjnych dla rodziny (Ostrowski 1998). Jak wskazuje bogata literatura krajowa i światowa, podjęcie aktywności zawodowej przez kobiety w działalności agroturystycznej motywowane jest następującymi potrzebami i czynnikami (Brandth, Haugen 2006; Getz, Carlsen 2000; Gidarakou i in. 2008; Jachimowicz, Krzyżanowska 2004; McGehee i in. 2007):

- potencjalnym wzrostem dochodów gospodarstwa (agroturystyka może być dodatkowym, uzupełniającym bądź głównym źródłem dochodu gospodarstwa);

- uaktywnieniem niewykorzystanych źródeł dochodu gospodarstwa w celu poprawy poziomu i jakości życia;

- możliwością uruchomienia sprzedaży organicznych produktów, wprowadzenia ekologicznej produkcji rolnej obok tradycyjnych form gospodarowania;

- potrzebą i możliwością dzielenia się doświadczeniem życia na wsi z innymi (np. odwiedzającymi gospodarstwo turystami) oraz chęcią kształtowania pozytywnego wizerunku pracy na wsi;

- chęcią poznania nowych ludzi;

- osiągnięciem satysfakcji z pracy w domu;

- realizacją hobby;

- stylem życia;

- chęcią samozatrudnienia, możliwością zatrudnienia członków rodziny; byciem dla siebie szefem;

- wykazaniem się aktywnością, gdy mąż pracuje poza gospodarstwem;

- porzuceniem pracy w gospodarstwie rolnym i stworzeniem sobie warunków lepszej pracy bez opuszczania domu;

- chęcią wsparcia wiejskiej gospodarki poprzez aktywizację nie najlepiej prosperujących gospodarstw rolnych.

Hansson i in. (2013), badając gospodarstwa prowadzące turystyczną działalność pozarolniczą w Norwegii, wskazali dwie grupy motywów leżących u podstaw 
aktywizacji pozarolniczej: rozwój biznesu, aby zmniejszyć ryzyko i wykorzystać istniejące zasoby gospodarstwa oraz rozwój działalności ze względów społecznych i poprawy jakości życia. W obu tych grupach motywy rozpoczynania nowych przedsięwzięć zależały od sytuacji rodzinnej (Hansson i in. 2013), a kobiety czuły się partnerami w kwestii decyzyjności w sprawach dotyczących gospodarstwa rolnego, domowego i rodzinnego (Gidarakou i in. 2008). Satysfakcja z wykonywanej samodzielnie pracy i poczucie niezależności to wysoce motywujące czynniki do pracy w agroturystyce według badań Sharpleya i Vassa (2006). Korzyści socjalne i finansowe z pracy w agroturystyce odpowiadają wniesionej przez kobiety pracy (Akpinar i in. 2005) oraz zrównują status kobiet i mężczyzn w rodzinie i gospodarstwie (Brandth, Haugen 2007), co również stanowi motywację do chętnego podejmowania pracy w agroturystyce częściej, aniżeli w rolnictwie.

\section{Cel pracy i metodologia badań}

Prezentowane powyżej zagadnienia badawcze stanowią punkt wyjścia do dyskusji na temat motywów podejmowania aktywności zawodowej przez kobiety w działalności agroturystycznej. Literatura sugeruje, iż motywy ekonomiczne (uzyskiwane środki finansowe) przeważają w kontekście odpowiedzi do rozważanego pytania: pracować zawodowo czy pozostać przy obowiązkach domowych? Jak ten dylemat odnosi się do społeczności góralskich rodzin tradycyjnych, która samą siebie uznaje za społeczność zamkniętą, hermetyczną, wyznającą tradycyjne wartości: rodziny i etosu pracy, oraz żyje poddana kontroli społecznej (Kurowska 2017)? Celem tego opracowania jest rozpoznanie motywów aktywności zawodowej kobiet w agroturystyce. Odpowiedź na tę kwestię ma nie tylko istotne znaczenie dla wyłonienia mechanizmów postrzegania motywów podjęcia aktywności zawodowej, którymi kierują się kobiety, ale również postrzegania tej aktywności przez członków rodzin. Prognozuje się, iż może mieć ona również kluczowe znaczenie dla budowania polityki wsparcia dla kobiet, które chcą się zawodowo rozwijać w agroturystyce.

Aby udzielić odpowiedzi na pytanie badawcze dotyczące zagadnienia motywów aktywizacji zawodowej, przeprowadzono badania eksploracyjne w wybranych grupach społecznych górali małopolskiej części polskich Karpat, których tradycyjny, wiejski styl życia i tożsamość dookreśla utrwalony wielowiekową tradycją system wartości. Społeczności te nadal cechują się silną wewnętrzną społeczną kontrolą oraz pewnym „zamknięciem” na wpływy zewnętrzne (Dobrowolski 1958; Kurowska 2017; Tomicki 1973). Gospodarstwa domowe górali karpackich to rodziny wielopokoleniowe, często prezentujące przykłady tradycyjnego rolnictwa. Można przypuszczać, że motywacje do podjęcia aktywności zawodowej kobiet w tradycyjnych rodzinach góralskich poprzez działalność agroturystyczną będą prowadzić 
do „przełamania” utrwalonego schematu dominacji motywów ekonomicznych nad innymi i wyłonienia grup motywów, które będą mieć swoje źródło w etosie pracy i wyznawanych wartościach.

Zważywszy na powyższe pytanie badawcze, a także wielopłaszczyznowy charakter badań nad motywami aktywizacji zawodowej kobiet w agroturystyce, zdecydowano o zastosowaniu jakościowej metody badawczej. Przy wykorzystaniu metod jakościowych interesuje nas szczególnie zakres i różnorodność perspektyw określonego zjawiska społecznego (Silverman 2000). Za wyborem metody jakościowej przemawiała również obawa o trudności w rekrutacji odpowiedniej liczby chętnych uczestników, która byłyby wystarczająca do rzeczowego badania ilościowego.

Szczegółowe badania na temat aktywności zawodowej kobiet w agroturystyce przeprowadzono w latach 2012-2014 z wykorzystaniem zweryfikowanego wcześniej kwestionariusza wywiadu. Badana próba liczyła 70 respondentek, prowadzących lub współprowadzących gospodarstwa agroturystyczne. Charakterystyka respondentek pod względem społeczno-demograficznym została przedstawiona w tabeli 1.

Badaniem objęto łącznie 70 gospodarstw, zlokalizowanych w 8 gminach karpackich województwa małopolskiego: Lipnica Wielka, Jabłonka, Czorsztyn, Ochotnica Dolna, Zawoja, Uście Gorlickie, Bukowina Tatrzańska, Kościelisko. Wybór obszaru badań został podyktowany tym, iż w tych 8 gminach obserwuje się od wielu już lat intensywny rozwój bazy agroturystycznej. Rekrutacja odbywała się poprzez osobiste i zawodowe kontakty autorki artykułu. Liczba wybranych do badań obiektów stanowiła 19,5\% bazy agroturystycznej, zlokalizowanej w części województwa małopolskiego położonej na terenie Karpat Polskich. Wraz z doborem celowym

Tab. 1. Wybrane cechy społeczno-demograficzne respondentek ( $\mathrm{N}=70)$

Table 1. Selected socio-demographic characteristics of the respondents $(\mathrm{N}=70)$

\begin{tabular}{|c|c|c|c|c|c|c|c|}
\hline $\begin{array}{c}\text { Zawód wyuczony } \\
\text { Previuos occupation }\end{array}$ & $\%$ & $\begin{array}{c}\text { Stan cywilny } \\
\text { Marital status }\end{array}$ & $\%$ & $\begin{array}{c}\text { Wiek } \\
\text { Age }\end{array}$ & $\%$ & $\begin{array}{c}\text { Wykszatacenie } \\
\text { Level of education }\end{array}$ & $\%$ \\
\hline $\begin{array}{c}\text { Związany z turystyką } \\
\text { Related to tourism }\end{array}$ & 21 & $\begin{array}{c}\text { Panna } \\
\text { Single }\end{array}$ & 6 & $18-34$ & 10 & $\begin{array}{c}\text { Wyższe } \\
\text { Higher }\end{array}$ & 14 \\
\hline $\begin{array}{c}\text { Niezwiązany z turystyką } \\
\text { Not related to tourism }\end{array}$ & 76 & $\begin{array}{c}\text { Mężatka } \\
\text { Married }\end{array}$ & 83 & $35-44$ & 16 & $\begin{array}{c}\text { Średnie i policealne } \\
\text { Secondary }\end{array}$ & 34 \\
\hline $\begin{array}{c}\text { Brak danych } \\
\text { No data }\end{array}$ & 3 & $\begin{array}{c}\text { Wdowa } \\
\text { Widow }\end{array}$ & 11 & $45-54$ & 34 & $\begin{array}{c}\text { Zawodowe } \\
\text { Vocational }\end{array}$ & 29 \\
\hline & & & & $55-64$ & 27 & $\begin{array}{c}\text { Podstawowe } \\
\text { Primary }\end{array}$ & 20 \\
\hline
\end{tabular}


próby zastosowano technikę tzw. kuli śniegowej, która polegała na wyszukaniu ze zbioru respondentów takich osób, które po przeprowadzonym wywiadzie prosi się o dostarczenie informacji potrzebnych do doboru kolejnych rozmówców (Babbie 2013). Przeprowadzone wywiady miały charakter eksploracyjny, gdyż analizowana problematyka na obszarze Karpat Polskich nie była dotychczas podejmowana.

Zebrany podczas wywiadów materiał został uporządkowany w tematy zaczerpnięte z literatury przedmiotu i wyników wywiadów. Podczas analizy wyników wykorzystano cytaty. Takie rozwiązanie pozwala zaprezentować i potwierdzić koncepcje powstałe w wyniku analizy tematycznej uzyskanych treści podczas wywiadów.

\section{Wyniki}

Gestorki w swych opiniach wskazywały wiele różnych przesłanek i motywów, jakimi kierowały się przy podjęciu działalności agroturystycznej. Były to motywy o charakterze ekonomicznym, społecznym oraz psychologicznym. Respondentki zazwyczaj nie ograniczały się do podania jednego głównego motywu, najczęściej podawano łącznie 2 lub 3 przyczyny podjęcia aktywności zawodowej w agroturystyce. Strukturę odpowiedzi prezentuje rycina 1. Najczęściej pojawiającym się motywem rozpoczęcia działalności agroturystycznej przez kobiety była świadomość zamieszkiwania w atrakcyjnej okolicy (74\% wskazań), która może być jednocześnie atrakcyjna dla turystów (ryc. 1). Zdaniem respondentek biorących udział w badaniu, to „piękna okolica” oraz „piękne tereny” skłaniają turystów do przyjazdu:

Præede wszystkim sktoniła do tego piękna okolica, w której żyjemy, teren, na którym jesteśmy wtaśnie. (Respondentka 19, 1. 31, mężatka);

(...) sktonita do tego piękna okolica, w której żyjemy, teren, na którym jesteśmy właśnie. Babia Góra jest dla nas btogostawieństwem, ale czasem i przeklenstwem [śmiech], poza tym w okolicy nie ma pracy dla mnie w præemyśle, toteż zdecydowatam, ふ̇e otworzymy gospodarstwo agroturystycæne. (Respondentka 13, 1. 45, mężatka).

W toku badań, w strukturze odpowiedzi jako równie istotną grupę motywów rozpoczęcia działalności agroturystycznej wskazywano lokalne tradycje turystyczne (69\% wskazań) (ryc. 1). Gestorki są świadome, w jakim miejscu mieszkają oraz cenią sobie własne środowisko kulturowe. W opinii respondentek, położenie gospodarstw agroturystycznych w regionie turystycznym Karpat Polskich traktowane jest jako wartość, atut. Gestorki opisują otaczające je tereny i doceniają ich walory przyrodnicze i turystyczne, wypowiadają się na temat okolicy z zamiłowaniem i sentymentem. Wiele gospodyń kontynuuje działalność agroturystyczną zapoczątkowaną przez swoich rodziców lub teściów (50\% wskazań) (ryc. 1), traktując to jako rodzinną tradycję: 


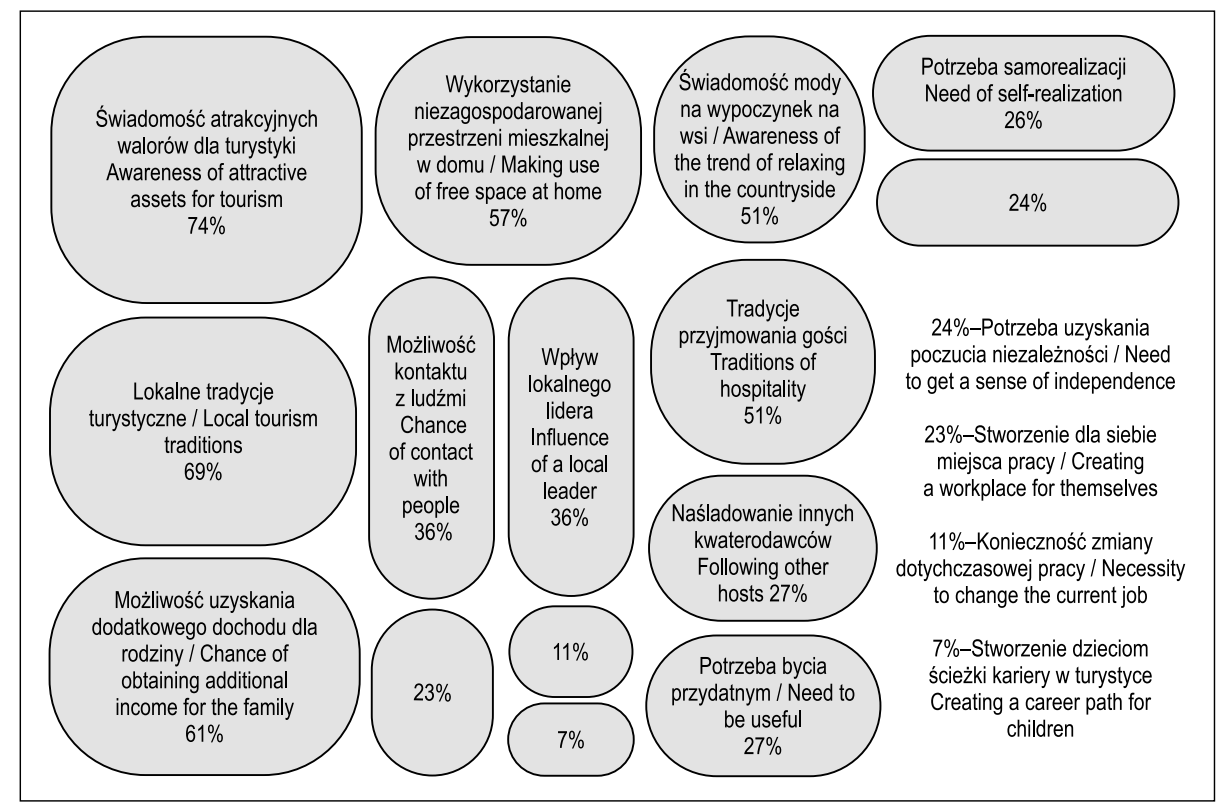

Ryc. 1. Motywy i czynniki rozpoczęcia działalności agroturystycznej przez kobiety

Fig. 1. Motives and factors of starting agritourism activity by women

Źródto: opracowanie własne na podstawie przeprowadzonych badań; liczby wewnątrz figur odpowiadają udziałowi [\%] respondentek, które podzielają tę opinię.

Source: own research; numbers within the figures correspond to the share [\%] of respondents who share this opinion.

Poza tym to wwiqzane jest \& tradycjami turystycznymi w tym rejonie oraz tradycja rodzinnq. Moja teściowa przyjmowata turystow w tym domu i kiedy wybudowali sobie inny dom i tam się præeprowad:ili, ja objętam po niej cześć gospodarstwa agroturystycznego na pót se swwagierkq. (Respondentka 40, 1. 34, mężatka);

Teściowie wynajmowali już pokoje turystom. Jak saczęta się budowa domu to się oka-

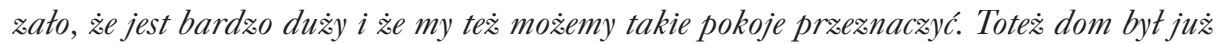
budowany z myślq o podnajmie pokoi. Tak te: pokoje zostaty saaran:̇oane pod turystów. (Respondentka 20, 1. 45, mężatka);

Spuścizna po rodzicach. Moi rodzice prowadzili gospodarstwo agroturystyczne i przyjmowali turystów. Dom i gospodarstwo odziedziczytam po rodzicach i chciatam dalej prowadzić to dla turystów. (Respondentka 33, 1. 29, mężatka);

Rodzice ju: przyjmowali turystów. Mo:̇na powiedzié́ tradycje rodzinne przyjmowania gości. Babcia - (...) prowadziła na bacówce PTTK, a rodzice przyjmowali w domu 
turystów. Mieli jeden pokój i mama mówi, ¿̇e oddawali im pokój, a sami spali w komórce na sianie. Potem mama kupiła tutaj dom, bysmy mieli z bratem blisko do sskoty. Tutaj tera: mamy agroturystykę. (Respondentka 5, 1. 51, mężatka);

Tu sq dtugie tradycje turystyczne w tym rejonie oraz tradycje rodsinne. Moja mama przyjmowata turystów i teraz ja kontynuuje prowadzenie gospodarstwa agroturystycznego. Moja mama jednak nie mogta dtugo żyć bez turystów $i$ w nowo wybudowanym domu te: otworzyli pensjonat. (Respondentka 39, 1. 42, mężatka).

Tradycje przyjmowania gości, według opinii gestorek, przekazywano w ich rodzinach z pokolenia na pokolenie.

W przypadku kobiet z obszarów wiejskich Karpat w granicach województwa małopolskiego, biorących udział w badaniu, interesujące wydaje się to, że przesłanki ekonomiczne i chęć uzyskania dodatkowego dochodu dla rodziny były wskazywane jako główny motyw jedynie przez około 2/3 badanych respondentek (61\% wskazań) (ryc. 1):

Byta to wtaśnie szansa na uzyskanie dodatkowego dochodu, na turystach kiedyś można byto zarobić. (Respondentka 17, 1. 63, mężatka);

Miatyśmy pokoje i powodem byta chęć zdobycia funduszy na utrzymanie rodziny. I ṡeby dom robit na siebie - tak to się mówi po gospodarsku. (...) Jest to dodatkowy dochód we lecie, aby móc przetrwać zimę. (Respondentka 43, 1. 58, wdowa).

Gestorki mają świadomość, że dochód z działalności agroturystycznej i wynajmowania do 5 pokoi turystom nie stanowi dużego przychodu gospodarstwa. Dlatego w wielu wypowiedziach łączono możliwość uzyskania dodatkowego dochodu także z chęcią wykorzystania niezagospodarowanej i wolnej (niezamieszkałej przez np. domowników) przestrzeni mieszkalnej w domu, jako „niewykorzystanego potencjału”:

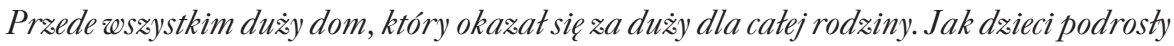
to zdecydowaliśmy, ¿̇e cæęśćpokoi præeznaczymy pod wynajem dla turystów. (Respondentka 23, 1. 71, mężatka);

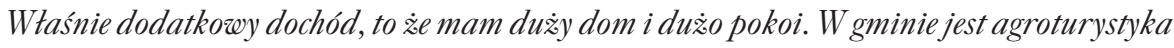

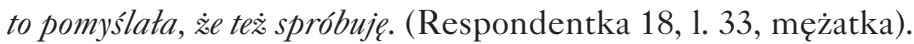

Wolne przestrzenie w domu pojawiały się w sytuacji wyjazdu dzieci na studia lub przeprowadzki dzieci do własnych domów w obrębie miejscowości rodzinnej albo w obliczu emigracji stałej poza lokalną miejscowość. Wówczas doskwierała gestorkom „pustka” lub „syndrom opuszczonego gniazda”. Dom miał wtedy „zarabiać na siebie" (Respondentka 43, 1. 58, wdowa).

Respondentki, odnosząc się do motywów podjęcia działalności agroturystycznej, łączyły je z początkami jej prowadzenia. Gospodynie rozpoczynały prowadzenie swojej działalności ze świadomością panującej ogólnie w świecie mody na wypoczynek na wsi (51\% wskazań) (ryc. 1). Wykorzystując sprzyjające okoliczności, podpatrywały i naśladowały rozwiązania innych kwaterodawców (27\% wskazań) (ryc. 1), np. w zakresie organizowania kolonii dla dzieci, pobytów rodzin, organizacji atrakcji, wykorzystania potencjału turystycznego miejscowości oraz miejscowej 
kultury itp. Respondentki w wypowiedziach wskazywały przypadki, kiedy budując nowe domy, planowały je z myślą o przeznaczeniu niektórych pięter lub pokoi na krótkoterminowy wynajem turystyczny:

Wszyscy prowadzili wynajem pokoi - byty potrzebne w sezonie, bo dusंo turystów co roku

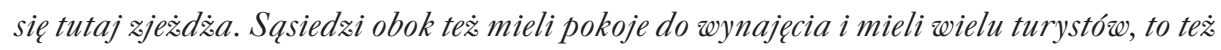
postanowiliśmy przygotować pokoje dla turystów. (Respondentka 37, 1. 63, mężatka);

Moda na wypoczynek na wsi, (...), poza tym tu w okolicy wiele osób przyjmuje kolonie, dzieci na oazy, parafie cate, takìe chciałam spróbować. Poza tym to zwiqzane jest z tradycjami turystycznymi w tym rejonie. Kilka przede mnq ju: prowadzito takie gospodarstwo i mnie sqsiedzi namówili. (Respondentka 25, 1. 48, mężatka).

Jak wynika z wielu wypowiedzi gestorek, podjęcie decyzji o rozpoczęciu działalności agroturystycznej związane było również z aktywną działalnością lokalnych liderów (36\% wskazań) (ryc. 1), którzy prowadzili już własne gospodarstwa agroturystyczne i dawali przykład innym przedsiębiorcom:

Przede wszystkim zmotywowaty mnie zebrania, spotkania w gminie na temat agroturystyki. Te sugestie pomogty mi podjać decyzje o otwarciu gospodarstwa agroturystycznego. (...) Wczesniej byto to gospodarstwo ekologiczne, to tatwiej nam byto zrobic gospodarstwo agroturystyczne. (Respondentka 4, 1. 74, mężatka);

Ja sie nastawiłam na wynajem turystom bodajìe w 1986 r. Zaczętam chodsic na sskolenia, które zaczęty się w 1990 r. jak kończyli budowę zapory, wtedy byty doradztwa rolnicze dla kobiet z kota gospodyń wiejskich i dla kobiet szkolenia pod agroturystykę. Ju: pomagali. Bo ludzie zaczęli budowaí domy, bo sie spodziewali, se będzie duso turystow

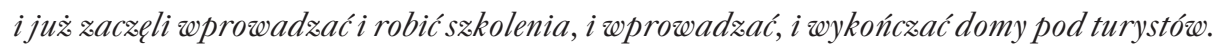
Jak ju: zalali jezioro w 1997 r. to ju: u nas byta petna agroturystyka. (Respondentka 43; 1. 58, wdowa).

Dzięki naśladowaniu rozwiązań wprowadzonych w miejscowości przez lokalnych liderów agroturystyki zorganizowano sieć gospodarstw agroturystycznych w Sromowcach Wyżnych i Niżnych oraz w Wysowej-Zdroju. Istotnym czynnikiem motywującym niektóre gestorki do podjęcia działalności agroturystycznej było wsparcie urzędów gmin, które organizowały wyjazdy studyjne dla potencjalnych kwaterodawców, na terenie kraju i za granicą. Motywujące, dla niektórych respondentek, okazało się również wsparcie szkoleniowe i organizacyjne świadczone przez gminy w zakresie prowadzenia działalności agroturystycznej.

Trzecia grupa motywów podjęcia działalności agroturystycznej ma charakter psychologiczny. Wśród nich gestorki wymieniały: możliwość kontaktu z nowymi ludźmi (36\% wskazań), potrzebę samorealizacji (26\%), potrzebę bycia przydatną (26\%), potrzebę uzyskania poczucia niezależności $(24 \%)$, stworzenie dla siebie odpowiedniego miejsca pracy (23\%), konieczność zmiany dotychczasowej pracy (11\%) oraz stworzenie dzieciom możliwości ścieżki kariery w turystyce (7\%) (ryc. 1): 
Chęć zarobienia pieniędzy, ale przede wszystkim: mo:́liwość kontaktu z ludঞ́mi. Synowie sie pożenili, wyjechali, zostat jeden, a dom stoi pusty. To zdecydowalismy o otwarciu gospodarstwa agroturystycznego. Nie lubię być sama w domu (...). (Respondentka 1, 1. 63, wdowa);

Jako mtoda osoba pracowatam w Jaszowcu w ośrodku Barbara (w Wiśle) i to zawsze byto moim marzeniem otworzyć coś wtasnego, uwielbiam kontakt z klientem i ta praca to daje. Traktujeje jako moje hobby i spetnienie marzen. (Respondentka 7, 1. 50, mężatka).

Spełnienie marzeń to, dla wielu gestorek, które wzięły udział w badaniu, jeden z silnych i popularnie wymienianych czynników motywujących. Gestorki poprzez swoją działalność nawiązywały nowe kontakty z ludźmi i poszukiwały nowych sieci kontaktów, poza swoim miejscem zamieszkania (36\% wskazań). Pojawiały się również opinie, że impulsem do podjęcia działalności były poprzednie doświadczenia zawodowe w pracy z ludźmi w turystyce, w szeroko podjętej działalności usługowej, m.in. w stołówkach szkolnych lub ośrodkach wczasowych, często z dziećmi (ryc. 1).

Do tej grupy motywów przyporządkowano również poczucie izolacji, braku celu w życiu jako motywację do rozwijania swojej działalności gospodarczej:

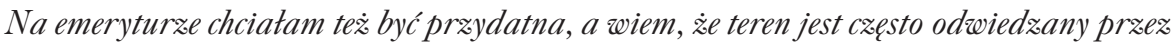
turystów, to postanowiliśmy z mę̇̇em udostęnić pokoje dla turystów (Respondentka 48, 1. 59, mężatka).

Istotnym motywem o charakterze psychologicznym podjęcia działalności agroturystycznej była możliwość wykreowania dla siebie nowego miejsca pracy (23\% wskazań), bardziej odpowiadającego potrzebom, w którym gestorki mogły podjąć pracę zawodową, inną od obowiązków związanych z gospodarstwem rolnym i domowym (ryc. 1):

(...) to byta sæansa na powrót do pracy, odskocænia od domowych obowiqæków. (Respondentka 19, 1. 31, mężatka);

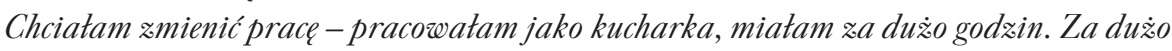
cঞasu spęd:atam w pracy, cora to więcej i nie miatam cæasu dla domu, dla rod:iny, dla siebie. Odesztam po 22 latach pracy i teraz mam wiecej czasu dla siebie, dla rodziny. To byta moja indywidualna decyzja - chciatam coś zmienić w swoim życiu i rodziny. (...) bo to jest idealna praca dla mnie (Respondentka 12, 1. 44, mężatka).

Zmiana uprawianego zawodu z powodów zdrowotnych, chęć zmiany pracy lub brak perspektyw na zatrudnienie skłaniały gestorki do stworzenia własnego przedsięwzięcia, dającego im sposobność realizacji zawodowej oraz kreowania dochodu w gospodarstwie, poza rolnictwem. Czynnikiem motywującym dla respondentek była również szansa przekwalifikowania się z dotychczas uprawianego zawodu (11\% wskazań) (ryc. 1):

Præede wszystkim gtównym motywem byta chęć posiadania wtasnych pieniędzy, nie będac pracownikiem. Trudna do pogodzenia jest praca na etat $i$ utrzymanie domu, a praca 
w domu, która przynosi pieniqdze, jest idealnym rowwiqzaniem. Poza tym chciatam mié́ pieniqdze, a nie czekać tylko na przyjazd mę̇a. A my mamy idealne warunki do prowadzenia agroturystyki. (Respondentka 6, 1. 50, mężatka);

Poz a tym to praca bardzo dobra dla mnie - nie musze wstawać codziennie rano, wystawać na przystankach, by dojechać do pracy, wstaje spokojnie, mam wolne weekendy $i$ du:o wolnego czasu - widzi Pani teraz siedze, popijam soczek, mam spokój i sæcæęście do tej pracy (Respondentka 14, 1. 50, mężatka).

Szczególnym czynnikiem było poczucie niezależności (24\% wskazań) (ryc. 1), które gestorki odczuwały i doświadczały z uwagi na możliwość zarabiania własnych pieniędzy (niezależność finansowa), ale też dzięki nowym aktywizującym obowiązkom:

(...) dodatkowe obowiqzki dla mnie, ale te: jest to moja dodatkowa praca w domu $i$ \&́ódto utrzymania - niewielkie sumy, ale sawsze. Daje mi to poczucie niezależności. (Respondentka 62, 1. 41, mężatka).

W toku badań zidentyfikowano opinie gestorek, iż działalność agroturystyczna we własnym gospodarstwie dała im możliwość kreowania miejsc pracy w działalności agroturystycznej nie tylko dla siebie, ale i dla swoich dzieci (7\% wskazań) (ryc. 1):

Moja córka teraz studiuje turystykę na AWF w Krakowie i te: chciałaby po studiach odæiedziczý́ gospodarstwo. Chciataby tutaj pracować(Respondentka 39, 1. 42, mężatka).

Gestorki zwracały uwagę, iż otwierając działalność, nie myślały tylko o perspektywie związanej z obecną sytuacją materialną gospodarstwa domowego, ale również o przyszłych pokoleniach. Była to szansa, inwestycja również na przyszłość, aby stworzyć miejsce pracy dla dzieci. Nie jest to jednak powszechne oczekiwanie wśród gestorek. Respondentki częściej dostrzegają lepszą przyszłość dla swoich dzieci w zdobyciu wyższego wykształcenia oraz w stałej emigracji ze wsi do większych ośrodków miejskich.

\section{Wnioski i podsumowanie}

Z wypowiedzi i opinii gestorek gospodarstw agroturystycznych, które wzięły udział w badaniu, wyłania się obraz motywacji, które wpłynęły na podjęcie przez nie aktywności zawodowej w agroturystyce. Motywy te można podzielić na 3 grupy: ekonomiczne; ,zewnętrzne” i „,wewnętrzne”, wywodzące się z przestrzennego otoczenia gospodarstwa oraz tradycji gościnności oraz ,indywidualistyczne” o podłożu psychologicznym i społecznym.

Głównym motywem, który jednocześnie stanowi podstawę pojawienia się pozostałych grup motywów podjęcia i podtrzymywania działalności agroturystycznej są przede wszystkim oczekiwane korzyści ekonomiczne. Zapewnienie dodatkowego dochodu dla gospodarstwa rodzinnego w postaci środków z działalności agroturystycznej leży u podstaw wprowadzenia agroturystyki w obręb działalności 
produkcyjnej gospodarstwa rolnego. Tym głównie kierują się gestorzy i gestorki obiektów przy wyborze dodatkowych działalności, które będą prowadzone w gospodarstwie rolnym.

W podjęciu decyzji o rozpoczęciu własnej działalności agroturystycznej w obrębie istniejącego gospodarstwa rolnego niezwykle istotną rolę odgrywają czynniki „zewnętrzne” płynące z przestrzennego otoczenia badanych gospodarstw rolnych. Do tej grupy należą: lokalne, miejscowe tradycje gościnności turystów, zdawanie sobie sprawy z poziomu rozwoju zjawisk turystycznych w miejscowości lub regionie, świadomość występowania atrakcyjnych walorów dla wypoczynku, które mogą być jednocześnie atrakcyjne dla przybywających turystów, bliskość cennej przyrody, tradycyjne życie i zwyczaje wsi. Bezpośrednio z nimi korespondują czynniki „wewnętrzne”, wynikające z zasobów gospodarstwa domowego i rolnego, takie jak: chęć wykorzystania niezamieszkałych i niezagospodarowanych, wolnych pomieszczeń we własnym domu oraz zwyczaj przyjmowania gości wynikający z rodzinnych tradycji.

Trzecią grupą motywów, które odgrywają równie niebagatelny wpływ na aktywność zawodową gestorek są motywy „indywidualistyczne” o podłożu psychologicznym i społecznym. Szczególnie odnoszą się one do kobiet i wiążą się z przypisywanymi im powszechnie kompetencjami osobowościowymi i społecznymi. W tej grupie zidentyfikowano takie motywy jak: potrzeba kontaktu z innymi ludźmi, bycie ,potrzebną” oraz potrzeba budowania „dla siebie i dzieci” ścieżki rozwoju osobistego.

Z wypowiedzi respondentek wynika wyraźnie, iż przychody z działalności agroturystycznej w większości przypadków badanych gospodarstw rolnych nie stanowią podstawy utrzymania badanych rodzin. Mimo to, możliwość ich uzyskiwania oraz związany z tym rozwój aktywności zawodowej jest czynnikiem umożliwiającym kobietom doświadczanie subiektywnego poczucia radości, zadowolenia, spełnienia, satysfakcji, „komfortu” psychicznego i niezależności. Ta niezależność ma charakter niematerialny, ale również materialny, dzięki uzyskanemu dochodowi z dodatkowej działalności gospodarstwa. Właśnie w dochodzie uzyskiwanym z usług świadczonych turystom kobiety, które wzięły udział w badaniu, postrzegają własny wkład w utrzymanie gospodarstwa domowego. Pomimo tego, że dochód ten daje im poczucie niezależności, spełnienia się w roli osoby utrzymującej gospodarstwo domowe, gestorki nie zawsze są skłonne do stwierdzenia, iż również taką drogę życia widzą dla swoich dzieci. Są świadome korzyści i wartości, jakie niesie ich aktywizacja zawodowa w agroturystyce. Niemniej jednak, nie zawsze oczekują podjęcia tej aktywności zawodowej przez ich dzieci, podobnej lub niemalże tej samej ścieżki rozwoju osobistego swoich dzieci. Respondentki nie zakładają, iż dzieci powtórzą ich wybory życiowe, co do obranej ścieżki rozwoju zawodowego w agroturystyce. Wiążą przyszłość dzieci ze zdobyciem wyższego wykształcenia, wolnym wyborem ścieżki zawodowej oraz stałą emigracją ze wsi do miast. 
Zidentyfikowane przez respondentki motywy podjęcia przez nie działalności gospodarczej w agroturystyce znajdują odzwierciedlenie w koncepcjach zakorzenionych w naukach społecznych i ekonomicznych: dywersyfikacji działalności gospodarczej gospodarstw rolnych, kapitału społecznego, rozwoju lokalnego i push/pull factors w kontekście przedsiębiorczości indywidualnych właścicieli gospodarstw rolnych. Gospodarstwa rolne wprowadzające nowe aktywności ekonomiczne do zakresu działalności czerpią potencjał z zasobów środowiska ich otaczającego. Wymaga to od nich wysokiej świadomości atrakcyjności tego środowiska oraz umiejętności adaptacji działalności własnych gospodarstw do warunków, jakie to środowisko stwarza oraz umiejętności wykorzystania jego zasobów dla celów rozwoju gospodarstwa. Narzuca to konieczność działań indywidualnych oraz często w skali całej rodziny zamieszkującej gospodarstwo domowe i rolne. Podstawą tych działań są więzi rodzinne, które motywują do podejmowania działalności ekonomicznych i innych, w celu zapewnienia bytu członkom rodziny. Wykorzystując lokalne zasoby ludzkie, ich wiedzę i wykształcenie, umiejętności, kreatywność, oraz zasoby środowiska otaczającego gospodarstwo, respondentki mają możliwość kreowania własnej lokalnej bazy ekonomicznej, która wpływa na poprawę sytuacji społeczno-gospodarczej rodziny. To kreowanie własnej lokalnej bazy ekonomicznej wymaga od respondentek twórczego myślenia, kreatywności, umiejętności oceny możliwości i szans ich wykorzystania, cech przywódczych i dobrej organizacji pracy. Gestorki nie tyle postawione są w sytuacji konieczności podjęcia aktywności zawodowej, ile same tę działalność wybierają i dostosowują do swoich potrzeb i możliwości jej podołania.

Motywy podjęcia aktywności zawodowej w agroturystyce przez gestorki biorące udział w badaniu, zidentyfikowane i wyszczególnione w niniejszym artykule, nakreślają potrzeby i oczekiwania kobiet wobec rynku pracy na obszarach wiejskich. Należy zauważyć, iż respondentki wykonywały obowiązki względem gospodarstwa agroturystycznego, rodzinnego i rolnego, a także część z nich była aktywna zawodowo i w okresie, w którym prowadzono badanie, wykonywały również pracę zawodową poza gospodarstwem rolnym i agroturystycznym. Biorąc pod uwagę sytuację kobiet na rynku pracy na obszarach wiejskich oraz kreślone możliwości zatrudnienia w ograniczonym obszarze gospodarki, można domniemywać, iż takie badanie ma szansę wskazać, w którym kierunku reformy ułatwiające podjęcie pracy przez kobiety z obszarów wiejskich powinny być inicjowane i wdrażane przez organy administracji regionalnej i ogólnokrajowej. Dodatkowo, takie badania pozwalają na wskazanie skutecznych metod i sposobów inicjowania i wdrażania działań oddolnych, które stwarzają warunki sprzyjające inicjowaniu procesów aktywizacji zawodowej kobiet w turystyce. Motywy te, wymienione przez gestorki, są jednocześnie oczekiwaniami kobiet wobec przyszłego rynku pracy dla nich oraz dla przyszłych pokoleń. Jest to ważne szczególnie z punktu widzenia rynków pracy, położonych w atrakcyjnie 
turystycznych obszarach, gdzie uczestniczki tego rynku wykazują się wysoką świadomością znaczenia wartości walorów turystycznych oraz możliwości ich wykorzystania dla dobra społeczności lokalnej i regionu.

Nadużyciem byłoby jednak twierdzenie, że problemy polskiego rynku pracy kobiet na obszarach wiejskich w ujęciu ekonomicznym rozwiąże jedynie aktywność zawodowa w turystyce, prowadzona w obrębie już istniejących gospodarstw rolnych, które zechcą dywersyfikować swoją działalność produkcyjną. Aktywność zawodowa kobiet w agroturystyce na obszarach wiejskich maskuje problemy strukturalne rynku pracy dla kobiet na obszarach wiejskich. Problemem tego rynku jest wciąż nieuznawanie przez opinię społeczną i państwo pracy w domu, np. w agroturystyce jako pracy zawodowej, co umniejsza jej znaczenie i nie daje podstaw do uzyskania Świadczeń emerytalnych, rentowych, ubezpieczeniowych ${ }^{1}$. Wciąż uznaje się te osoby za bierne zawodowo, pomimo świadczenia przez nie pracy na rzecz członków rodziny i turystów.

Dodatkowo, praca nie zaspokaja jedynie potrzeb ekonomicznych, ale także potrzeby społeczne i psychologiczne kobiet, wynikające z ich aktywności zawodowej. Praca w wymiarze społecznym i psychologicznym jest równie potrzebna, aby tworzyć solidarne i szczęśliwe społeczeństwo żyjące w otoczeniu zapewniającym wysoką i satysfakcjonującą jakość życia.

Wyniki badań omówione w artykule są częścią rozprawy doktorskiej pt. Agroturystyka jako czynnik aktywiæacji zawodowej kobiet na obssarach górskich wojewódwtwa matopolskiego. Finansowano je ze środków DSC Wydziału Biologii i Nauk o Ziemi Uniwersytetu Jagiellońskiego w Krakowie w latach 2012-2013 (K/DSC/000910).

\section{Literatura:}

Akpinar N., Talay I., Ceylan C., Gunduz S., 2005, Rural women and agrotourism in the context of sustainable rural development: A case study from Turkey, Environment, Development and Sustainability, 6, 473-486.

Alsos G.A., Ljunggren E., Pettersen L.T., 2003, Farm-based entrepreneurs: What triggers the start-up of new business activities?, Journal of Small Business and Enterprise Development, $10,435-443$.

Babbie E., 2013, Podstawy badań spotecznych, Wydawnictwo Naukowe PWN, Warszawa.

Barbieri C., Mahoney E., 2009, Why is diversification an attractive farm adjustment strategy? Insights from Texas farmers and ranchers, Journal of Rural Studies, 25, 58-66.

Barrett C.B., Reardon P., Webb P., 2001, Nonfarm income diversification and household livelihood strategies in rural Africa; concepts, dynamics and policy implications, Food Policy, 26, 315-331.

\footnotetext{
${ }^{1}$ Kubal, Mika (2012).
} 
Bartkowski J., 2008, Regionalne zróínicowanie kapitatu spotecznego w Polsce, Przegląd Socjologiczny, LVII/1, 63-80.

Bowler I., 1999, Modelling farm diversification in regions using expert and decision support systems, Journal of Rural Studies, 15, 297-305.

Brandth B., Haugen M.S., 2006, Emotional work in host-guest relations. Examples from farm tourism, Paper no 2/06, presented at the Research Partners' Meeting 'Crossroads of tourism and work' in Kilpisjärvi, Finnish Lapland, 21-24 May 2006.

Brandth B., Haugen M.S., 2007, Gendered work in family farm tourism, Journal of Comparative Family Studies, 38 (3), 379-393.

Bukraba-Rylska I., 2008, Socjologia wsi polskiej, Wydawnictwo Naukowe PWN, Warszawa.

Dobrowolski K., 1958, Chtopska kultura tradycyjna: Próba teoretycznego zarysu na podstawie materiatów śódtowych XIX i XX w. z potudniowej Małopolski, Etnografia Polska, 1, 19-56.

Działek J., 2011, Kapitat spoteczny - ujęcia teoretyczne i praktyka badawcza, Studia Regionalne i Lokalne, 3 (45), 100-118.

Fedyszak-Radziejowska B., 2006, Czy kapitat spoteczny bez spotecznego zaufania jest możliwy?, [w:] K. Szafraniec (red.), Jednostkowe i spoteczne zasoby wsi, Instytut Rozwoju Wsi i Rolnictwa PAN, Warszawa, 123-146.

Frykowski M., Starosta P., 2006, Kapitat spoteczny na terenie wojewódstwa tódzkiego, [w:] K. Gorlach, G. Foryś (red.), W obliczu zmiany: Wybrane strategie działania mieszkańców polskiej wsi, Wydawnictwo Uniwersytetu Jagiellońskiego, Kraków, 79-106.

Getz D., Carlsen J., 2000, Characteristics and goals of family and owner-operated business in the rural tourism industry and hospitality sectors, Tourism Management, 21 (6), 547-560.

Gidarakou I., Dimopoulou E., Lagogianni R., Sotiropoulou S., 2008, Young women and agriculture - The case of active young women farmers in West Macedonia, Greece, [w:] H. Coccossis, Y. Psycharis (red.), Regional Analysis and Policy. The Greek experience, Physica-Verlag HD, Heidelberg, 355-374.

Gorlach K., 2007, Różne oblic»a globaliæacji i ich rola w rozwoju obsæarów wiejskich, Materiały konferencyjne: Globalizacja w rolnictwie, 13 września, Warszawa.

Halamska M., 2009, Kapitat spoteczny wsi: Jego stan, tendencje, możliwości wzmocnienia, [w:] K. Duczkowska-Małysz, A. Szymecka (red.), Wokót trudnych problemów globalnego rozwoju obszarów wiejskich, gospodarki żywnościowej i rolnictwa, SGH, Warszawa, 306-307.

Hansson H., Ferguson R., Olofsson Ch., Rantamäki-Lahtinen L., 2013, Farmers' motives for diversifying theirfarm business - The influence of family, Journal of Rural Studies, 32, 240-250.

Hisrich R.D, Pater M.P., 1992, Entrepreneurship. Starting, developing and managing a new enterprise, Irwin, Boston.

Hunek T., 1993, Makroekonomične uwarunkowania rowwoju „small bussinessu” na terenach wiejskich, [w:] K. Duczkowska-Małysz (red.), Przedsiębiorczośćn na obszarach wiejskich. W stronę wsi wielofunkcyjnej, Instytut Rozwoju Wsi i Rolnictwa PAN, Warszawa, 13-22. 
Jachimowicz E., Krzyżanowska K., 1998, Subiektywne czynniki rozwoju turystyki wiejskiej, [w:] Zrównoważony rozwój turystyki wiejskiej - idee, działania, efekty, CDRiEwR Kraków, $113-117$.

Jachimowicz E., Krzyżanowska K., 2004, Pozarolnicze funkcje gospodarstwa rolnic«ego na przyktadzie jego dziatalności agroturystycznej, Wydawnictwo SGGW, Warszawa.

Janiak K., 1996, Potrzeby i motywy podejmowania pozarolniczej dziatalności gospodarczej przez rolników, Zagadnienia Doradztwa Rolniczego, 1, 71-75.

Jarosz A., 1996, Agroturystyka szansq rozwoju wsi i rolnictwa, [w:] A. Jarosz (red.), Agroturystyka jako szansa aktywizacji gospodarcæej wiejskich regionow turystycznych Matopolski Wschodniej, Oficyna Wydawnictwo Politechniki Rzeszowskiej, Rzeszów-Boguchwała, 83-94.

Kłodziński M., 1996, Wielofunkcyjny rozwój terenów wiejskich w Polsce i krajach Unii Europejskiej, Wydawnictwo SGGW, Warszawa.

Kłodziński M., 1999, Aktywiæacja gospodarcæa obsæarów wiejskich, Instytut Rozwoju Wsi i Rolnictwa PAN, Centrum Naukowo-Wdrożeniowe SGGW, Warszawa.

Kłodziński M., Rosner A., 1995, Wielofunkcyjny rowwój terenów wiejskich a polityka regionalna, [w:] K. Duczkowska-Małysz, S. Kłodziński, Cz. Siekierski (red.), Polityka regionalna w rozwoju obszarów wiejskich, Materiały z ogólnokrajowej konferencji 30-31 marca 1995 r. SGGW, Warszawa.

Kołodziejczak A., 2004, Działalnośćpozarolnicza gospodarstw rolnych zlokalizowanych na obszarach o niekorzystnych warunkach dla produkcji rolnej, [w:] E. Pałka (red.), Pozarolnicza działalność gospodarcza na obszarach wiejskich, Studia Obszarów Wiejskich, 5, Warszawa, 45-56.

Kołodziejczyk D., 2004a, Kierunki rowwoju pozarolniczej dziatalności gospodarczej na obszarach wiejskich, [w:] J. Bański (red.), Polska przestræeń wiejska: Procesy i perspektywy, Studia Obszarów Wiejskich, t. VI, Komisja Obszarów Wiejskich PTG, Instytut Geografii i Przestrzennego Zagospodarowania im. S. Leszczyckiego PAN, Warszawa, 39-58.

Kołodziejczyk D., 2004b, Pozarolnicะa działalność gospodarcza w indywidualnych gospodarstwach rolnych w skali gmin, [w:] E. Pałka (red.) Pozarolnicæa dziatalność gospodarcza na obsæarach wiejskich, Studia Obszarów Wiejskich, 5, Warszawa, 23-34.

Koutsou S., Notta O., Samathrakis V., Partalidou M., 2010, Women's entrepreneurship and rural tourism in Greece: Private enterprises and cooperatives, South European Society and Politics, 14, 191-209.

Kryński Z., 2003, Czynniki i motywy warunkujqce rozwój agroturystyki, [w:] A. Mirończuk (red.), Turystyka wiejska i agroturystyka. Stan i perspektywy rozwoju, Wydawnictwo Akademii Podlaskiej, Siedlce, 155-170.

Kryński Z., Kusz D., Augustyńska-Prejsnar A., 2002, Motywy podejmowania dziatalności agroturystycznej, [w:] Z. Kryński, E. Kmita-Dziasek (red.), Turystyka wiejska a rozwój i wspótpraca regionów, Materiały Sesji Naukowej zorganizowanej w ramach XI Ogólnopolskiego Sympozjum Agroturystycznego, Prace Naukowo-Dydaktyczne PWSZ w Krośnie, 15, Centrum Doradztwa Rolniczego w Brwinowie, O. w Krakowie, Podkarpackie Stowarzyszenie Agroturystyczne „Gospodarstwa Gościnne”, Krosno. 
Kubal M., Mika M., 2012, Agritourism in Poland - the legal model and the realities of the market, Current Issues of Tourism Research, 2 (1), 4-11.

Kurek W., 1995, Gospodarstwa agroturystyczne w Karpatach, Turyzm, 5 (2), 77-86.

Kurowska K., 2017, Rodzina podhalańska - raport z badań, Tematy z Szewskiej, Rodzina, 2 (19), 21-31.

Łobocki J., 2006, Agroturystyka jako forma dywersyfikacji wykorzystania obszarów wiejskich, [w:] M. Sirko, J. Bek (red.), Rola turystyki w rozwoju gospodarczym obswarów wiejskich i lesnych, WSE, Stalowa Wola.

McGehee N.G., Kim K., 2004, Motivation for agri-tourism entrepreneurship, Journal of Travel Research, 43, 161-170.

McGehee N.G., Kim K., Jennings G.R., 2007, Gender and motivation for agri-tourism entrepreneurship, Tourism Management, 28 (1), 280-289.

Meert H., Van Huylenbroeck G., Vernimmen T., Bourgeois M., van Hecke E., 2005, Farm household survival strategies and diversification on marginal farms, Journal of Rural Studies, 21, 81-97.

Michalska S., 2012, Spoteczny wymiar funkcjonowania drobnych gospodarstw rolnych, Problemy Drobnych Gospodarstw Rolnych, 1, 85-93.

Nowak S., 2012, Metodologia badań spotecznych, Wydawnictwo Naukowe PWN, Warszawa.

Ostrowski L., 1998, Kobiety wiejskie - praca i warunki bytu, Studia i Monografie, Instytut Ekonomiki Rolnictwa i Gospodarki Żywności, Warszawa.

Pawlusiński R., 2005, Samoræad lokalny a rozwój turystyki. Przykład gmin Wyżyny Krakowsko-Cæęstochowskiej, Instytut Geografii i Gospodarki Przestrzennej UJ, Kraków.

Peeters L.W.J., Ateljevic I., 2009, Women empowerment entrepreneurship nexus in tourism: Process of social innovation, [w:] S. Page, I. Ateljevic (red.), Tourism and entrepreneurship: International perspectives, Butterworth-Heinemann, Oxford, 75-90.

Phelan C., Sharpley R., 2011, Exploring agritourism entrepreneurship in the UK, Tourism Planning \& Development, 8 (2), 121-136.

Phelan C., Sharpley R., 2012, Exploring entrepreneurial skills and competencies in farm tourism, Local Economy, 27 (2), 103-118.

Runowski H., Siekierski Cz., 1995, Regionalne uwarunkowania rozwoju rolnictwa, [w:] K. Duczkowska-Małysz, S. Kłodziński, Cz. Siekierski (red.), Polityka regionalna w rozwoju obszarów wiejskich, Materiały z ogólnokrajowej konferencji 30-31 marca 1995 r., SGGW, Warszawa.

Sawicki B., 2007, Agroturystyka w aktywizacji obsæarów wiejskich, AR w Lublinie, Lublin.

Scheyvens R., 2000, Promoting women's empowerment through involvement in ecotourism: Experiences from the third world, Journal of Sustainable Tourism, 8 (3), 232-246.

Schjoedt L., Shaver K.G., 2007, Deciding on an entrepreneurial career: A test of the pull and push hypotheses using the panel study of entrepreneurial dynamics data, Entrepreneurship Theory and Practice, 31, 733-752.

Seręga Z., 1993, Czynniki rozwoju lokalnego: Studium socjologiczne wybranych spoteczności wiejskich, Rozprawy Habilitacyjne Uniwersytetu Jagiellońskiego, 265, Kraków. 
Shane S., 2003, A general theory of entrepreneurship. The individual opportunity, Nexus, Edward Edgar Publishing Inc., Massachusetts.

Shane S., Venkataraman S., 2000, The promise of entrepreneurship as a field of research, The Academy of Management Review, 25 (1), 217-226.

Sharpley R., Vass A., 2006, Tourism, farming and diversification: An attitudinal study, Tourism Management, 27 (5), 1040-1052.

Silverman D., 2000, Doing qualitative research - A practical handbook, SAGE, London, Stownik jezyka polskiego PWN, 2015, Wydawnictwo Naukowe PWN, Warszawa.

Sołoma L., 2002, Metody i techniki badań socjologicznych: Wybrane zagadnienia, Wydawnictwo Uniwersytetu Warmińsko-Mazurskiego, Olsztyn.

Szymańska D., 2009, Geografia osadnictwa, Wydawnictwo Naukowe PWN, Warszawa.

Tew C., Barbieri C., 2012, The perceived benefits of agritourism: The provider's perspective, Tourism Management, 33, 215-224.

Tomicki R., 1973, Tradycja i jej znaczenie w kulturze chtopskiej, Etnografia Polska, XVII, Warszawa, 41-58.

Ustawa \& dnia 20 kwietnia 2004 r. o promocji zatrudnienia i instytucjach rynku pracy, Dz.U. 2004 nr 99 poz. 1001.

Wójcik M., 2011, Wiejski obszar peryferyjny w koncepcjach geograficznych, [w:] M. Wesołowska (red.), Wiejskie obsæary peryferyjne - uwarunkowania i czynniki aktywizacji, Studia Obszarów Wiejskich, t. XXVI, Komisja Obszarów Wiejskich PTG, Instytut Geografii i Przestrzennego Zagospodarowania im. S. Leszczyckiego PAN, Warszawa, 19-34.

\author{
Magdalena Kubal-Czerwinska \\ Uniwersytet Jagiellonski \\ Instytut Geografii i Gospodarki Przestrzennej \\ ul. Gronostajowa 7, 30-348 Kraków \\ magdalena.kubal@uj.edu.pl
}


